\title{
EUCALYPTUS AND SENGON PLANTS FOR COAL MINING RECLAMATION IN BARITO EAST DISTRICT, CENTRAL KALIMANTAN PROVINCE
}

\author{
Ermal Subhan \\ Environmental Science Study Program, Post Graduate Study Program of Palangka Raya \\ University, Palangka Raya, Indonesia. \\ Salampak \\ Department of Agro Technology, Faculty of Agriculture, Palangka Raya University, \\ Palangka Raya, Indonesia.

\section{Andria Elia Embang} \\ Department of Development Economics, Faculty of Economics and Business, \\ Palangka Raya University, Palangka Raya, Indonesia.

\section{Masliani} \\ Department of Agribusiness, Faculty of Agriculture, Palangka Raya University, \\ Palangka Raya, Indonesia.

\section{Yetrie Ludang} \\ Department of Forestry, Faculty of Agriculture, Palangka Raya University, \\ Palangka Raya, Indonesia.

\section{Adi Jaya} \\ Department of Agro Technology, Faculty of Agriculture, Palangka Raya University, \\ Palangka Raya, Indonesia.
}

\begin{abstract}
This study aims specifically to produce an analysis of the suitability of forest plantations on former coal mining land. The research was conducted in two stages. The first stage is a general description of the research area and the second stage is the study of the suitability of forest plantations on former coal mining land. Eucalyptus was chosen because it is able to grow both on marginal lands and in swamps and waterlogging areas, able to adapt to soils with poor drainage, fire resistance and tolerance to soils with low to high salinity. This Sengon plant was chosen because it has the advantage of very fast growth, very diverse uses, and can grow on critical land.
\end{abstract}


Keywords: Eucalyptus, Sengon, land reclamation

Cite this Article: Ermal Subhan, Salampak, Andria Elia Embang, Masliani, Yetrie Ludang, Adi Jaya, Eucalyptus and Sengon Plants for Coal Mining Reclamation in Barito East District, Central Kalimantan Province, International Journal of Advanced Research in Engineering and Technology (IJARET), 11 (1), 2020, pp 14-22. http://iaeme.com/Home/issue/IJARET?Volume=11\&Issue $=1$

\section{INTRODUCTION}

Ex-mining mining land needs to be immediately reclaimed and replanted to restore the ecosystem and microclimate, soil fertility and water storage functions. Reclamation characteristics are open space, high light intensity, high temperature and extreme fluctuation, low $\mathrm{pH}$ and degradation of the number of species both flora, fauna and soil microorganisms. Such characteristics cause not all types of plants can live on the land (Rahmawaty, 2002).

The implementation of reclamation has not been done well. It still looks like the former excavation, most of which have been filled with water and arrangement. Replanting activities have not been done well because some of the ex-mining land has not yet been planted and in areas where reclamation has been carried out partly planting has not been planted cover crop and tree growth is uneven this can be said to be lack of plant maintenance and care.

In order to improve and refine the reclamation and revegetation activities, one way to overcome this problem is to conduct a reclamation study of the former coal mining land using eucalyptus forest plants (Melaleuca leucadendra) and Sengon (Paraserianthes falcataria).

Eucalyptus plants will be used as shrubs, and Sengon as a staple crop. Referring to the background of the research and identification of problems, the problem formulation was prepared as follows: how is the suitability of the forest cultivation land on the former coal mining land?

The main objective of this research is to make a study of land reclamation of coal mining using forest plant cultivation. The specific objectives of this study can be described as follows: Analyzing the suitability of forest plantations on former coal mining land.

Replanting activities using Sengon plants and eucalyptus plants are used as tree plants and shrubs. Considerations include ecology, economics and social. Ecologically the development of eucalyptus plants in degraded land, among others, is to support efforts to conserve land and use marginal land into productive land. Economically the development of eucalyptus and sengon plants can be used as a business both on a household scale and large scale and socially does not cause community conflict. The results of this study are expected to be a policy reference for the Central Kalimantan Provincial Regulations on guidelines for reclamation and post-mining of coal mining materials.

\section{METHODOLOGY}

This research was conducted in two stages to answer the research objectives, starting in January to December 2019, with the description of the stages in the following discussion.

\subsection{Phase I Research (Preliminary Research: An Overview of the Study Area)}

The first phase of this research is a preliminary study that aims to determine the representative location and time of the study, as well as the location of sampling and observation of physical properties in the next stage of research. 


\subsubsection{Place and Time}

Phase I research activities (preliminary research) in the form of surveys and field observations carried out at the Mining Business License Location (PT) Senamas Energindo Mineral administratively located in the Districts of East Dusun, Karusen janang, and Awang District, East Barito, Central Kalimantan Province. The study of supporting data in the form of primary data was carried out in the Post Mining Mining Area of PT. Senamas Energindo Mineral (PT. SEM). This research study was conducted at PT. SEM, because PT. SEM is willing to facilitate research activities. Secondary data studies were carried out at the closest Meteorological Station to the study site and in the Post Mining Mining Area of the research representative Mining Company. The survey was carried out for 1 (one) month and a secondary data study was carried out for 1 (one) month.

\subsubsection{Materials and Tools}

The material used in the form of ex-coal mining land at PT. SEM as a representative of the research location.

The tools used are: GPS to find out the coordinates of the sampling location, a camera to document research activities, sample bags and other stationery.

\subsubsection{Research Implementation}

Field survey activities are carried out before the main research begins with a view to:

1) Obtain and determine the location of research representatives at the Coal Mining Business License Location in Central Kalimantan.

2) Conduct a study of the development of activities at the Coal Mining Business Permit Location that has been determined as the location of the research representative.

3) Conduct observations on blocks in the Coal Mining Business Permit Location that have been designated as locations for research representatives to obtain representative location blocks for observation and soil sampling at the next stage of research.

4) Conduct a study of research supporting data in the form of secondary data, consisting of: climate, flora and fauna, population and economic data, morphology and soil types, geology and coal mining in the study area. Climate data were obtained from the Climatology Station in the area closest to the study site. Population and economic depictions were obtained in the closest related department to the study location, and flora and fauna, morphology and soil types, geology and coal mining were obtained from coal mining companies that have been designated as locations for research representatives, namely PT. SEM.

Determination of the representative location and time of the study, as well as observation of physical properties and sampling at the next stage of the research are determined based on a general description of the condition of the study area obtained when conducting survey activities in the field, because this greatly affects the reclamation activities on the former coal mining land.

\subsection{Phase II Research (Assessment of Suitability of Forest Plantations on Ex-coal Mining Land)}

This phase II study aims to analyze the suitability of forest plantations on ex-coal mining land.

\subsubsection{Place and Time}

Based on the results of preliminary research, phase II research was carried out at the Mining Business License Location of PT. Senamas Energindo Mineral (PT. SEM) is administratively located in the Districts of East Hamlet, Karusen janang, and Awang District of East Barito Regency, Central Kalimantan Province with an area of \pm 2000 ha. Mining Business Permit in 
accordance with the Decree of the Regent of East Barito Number 516 of 2009 dated December 8, 2009. Sampling of land was carried out in the post-mining area of PT. SEM. Soil samples obtained were analyzed at the UPT Integrated Laboratory of Palangka Raya Calibration PT. Unilab Perdana Surabaya. The time of the second phase of the research from preparation to obtaining secondary data and field data is carried out for 10 (ten) months, starting in March to December 2019.

\subsubsection{Materials and Tools}

The materials used in this study are: soil and water samples (waste and river water) in PT SEM's coal mining estate in 4 mining blocks with an area per block of 500 ha, the total area under study is 615.75 ha.

The tools used in this study are: soil sample bags, Drone Phontom 4, Global Positioning System (GPS), $\mathrm{pH}$ meter, geological compass, mine / rope, denometer, hoe, meter, hand drill, picket, bottle, label paper, markers permanent, sample boxes, machetes, boots, safety equipment in the field, cameras to document research activities, and other stationery such as in phase 1 research.

\subsubsection{Research Implementation}

This research is a field research, carried out using quantitative-qualitative-descriptive methods by using surveys or direct observations to collect data and information needed. Descriptive research is research aimed at describing or describing a phenomenon in the hope of producing an accurate picture of a phenomenon, the mechanism of a process, and explaining a set of stages or processes. Stages of research sourced from primary and secondary data stages of the study, the complete stages of the study are described below.

The second phase of this research was conducted in 2 (two) stages: the first stage was collecting secondary data, and the second stage was collecting primary data and analyzing data. Research methods that are closely related to the objectives of this study, each analysis method is described as follows.

\section{RESULTS AND DISCUSSION}

The results of the study of land reclamation of coal mining using forest plants at each stage of the study are described in the following discussion.

\subsection{Phase I Research (Overview of Research Sites)}

The first phase of this research is a preliminary study that aims to determine the location of representatives and the time of the study, as well as the location of sampling and observation of physical properties in the next stage of research.

Phase I research activities (preliminary research) in the form of surveys and field observations carried out at the Mining Business License Location (PT) Senamas Energindo Mineral administratively located in the Districts of East Dusun, Karusen janang, and Awang District, East Barito, Central Kalimantan Province. The study of supporting data in the form of primary data was carried out in the Post Mining Mining Area of PT. Senamas Energindo Mineral (PT. SEM). This research study was conducted at PT. SEM, because PT. SEM is willing to facilitate research activities. Secondary data studies were carried out at the closest Meteorological Station to the study site and in the Post Mining Mining Area of the research representative Mining Company.

Based on the results of preliminary research studies, it is obtained the focus of the representative location for soil sampling and observation of the physical properties which were examined in the subsequent research stages determined at PT. Senamas Energindo 
Mineral which is administratively located in the Districts of East Hamlet, Karusen janang, and Awang District of East Barito Regency, Central Kalimantan Province.

The results of the secondary data study in the form of climate in the study location show that monthly rainfall is $319.39 \mathrm{~mm} /$ month, minimum average temperature is $21.90 \mathrm{oC}$ and maximum temperature is $34.70 \mathrm{oC}$, minimum humidity is $53.80 \%$ and maximum humidity is $99.60 \%$. The highest rainfall occurs in November while the lowest occurs in June and August, while the highest rainy day occurs in December and the lowest in August. Rain types in the study area are Type A, characterized by no dry months $(<60 \mathrm{~mm})$ and the number of wet months $=12$ months. The ratio between dry and wet months is 0 or $\mathrm{Q}=0$. The type of forest vegetation (flora and fauna) is quite diverse. Total population of 97,372 people, consisting of $51.46 \%$ of men and $48.54 \%$ of women, population density is classified as sparse, which is about 25 people per km2. Number of Households Total 2018 of 25,591 households spread in 10 districts. The sub-district with the highest and most populous population is the Central Hamlet with a population of 22,578 people and a density of 60.86 people $/ \mathrm{km}^{2}$. The subdistrict with the lowest population and density is Paju Epat sub-district with a population of 3,990 people and a density of 6.01 people $/ \mathrm{km}^{2}$ (BPS, 2018). Based on the map of soil types in Central Kalimantan Province, it can be seen that the type of land in the entire Mining Business License of PT. SEM has a high elemental content of aluminum and iron. PT. Senamas Energindo Mineral area (2,000 hectares) is podzolik land. Podzolic soil is land formed in areas that have high rainfall and low temperatures. The soil has moderate fertility characteristics, characterized by red or yellow color having clay texture or sand having a low $\mathrm{pH}$. The mining method used by PT. Senamas Agrobindo Mineral uses the open pit method.

\subsection{Phase II Research (Assessment of Suitability of Forest Plantations on Ex-coal Mining Land)}

Based on the results of the study that have been determined in the first phase of research, that the location of the observation of physical properties and soil sampling in the second phase of the research was carried out in the former coal mining area of 4 blocks with an area of 615.75 ha (presented in figure 5.1) PT. Senamas Energindo Mineral which is administratively located in the Districts of East Hamlet, Karusen janang, and Awang District of East Barito Regency, Central Kalimantan Province. The time of the research in this phase II research was carried out for 10 (ten) months from preparation to obtaining secondary data and field data.

\subsubsection{Soil Physical Properties}

The results of the analysis of soil physical properties were carried out in the analysis of soil texture classes. Based on the analysis of soil samples in the laboratory shows that the soil texture class at the location of the former coal mining at PT. SEM is broadly classified as sandy loam. Laboratory analysis results show that the lowest sand content is $1.45 \%$ and the highest is $14.71 \%$. The lowest dust content is $26.05 \%$ and the highest is $42.7 \%$. The lowest clay element is $0.55 \%$ and the highest is $0.64 \%$.

The distribution of soil particle size shows that the soil particle size at the study site has fulfilled the requirements for agricultural land which requires a texture range between clay, dusty loam to sandy loam (Djaenuddin et al., 1994). In relation to plant cultivation, soil texture influences the ease of tillage, the availability of water for plants, and the determination of nitrogen requirements for plants. Sand textured soil, for example, is easy to cultivate but is less able to provide water for plants, the opposite condition occurs in clay, clay / dusty clay. In relation to nitrogen requirements, soils with a sand content of less than $65 \%$ require nitrogen between 100 to $200 \mathrm{~kg} / \mathrm{ha}$, whereas if the sand content is above $70 \%$, the nitrogen needed is more than $200 \mathrm{~kg} / \mathrm{ha}$. 
Volume weight, total porosity and permiability are three variables related to soil density. The results showed that the level of soil density in the former coal mining land was relatively in line with the requirements for the growth of food crops, plantations and animal feed plants, with bulk density values ranging from 1.57 to 1.7 g.cm3 and particle density ranged from 1.98 to 2.35 g.cm- 3 Soil porosity ranged from $14.14 \%-32.34 \%$ and soil permiability ranged from $1.75-2.29$, classified as rather slow to moderate. The level of soil density in the former coal mining area at the research location has a quality that still meets the requirements of plant growth. However, land management actions must still be taken when the former mining land is converted into agricultural land for food crops, plantations, fodder crops and agroforestry or for other uses such as ecotourism because each type of plant and building has a different response to density.

\subsubsection{Soil Chemical Properties and Soil Fertility}

The results of the analysis of the soil chemical properties in the former coal mining area of PT. SEM as a representative of research locations varies greatly. Data from the results of laboratory analysis of soil chemical properties at the study site shows that the C-organic content in the former coal mining area of PT. SEM locations R1 to R5 are classified as very low, with the lowest organic $\mathrm{C}$ value at location $\mathrm{R} 2$ of $0.16 \%$ the highest at location $\mathrm{R} 1$ of $0.24 \%$. The nutrient content of $\mathrm{N}$ is classified as moderate to very high, with the lowest $\mathrm{N}$ content at location R2 of $0.45 \%$ and the highest at location R 3 of $1.55 \%$. The P content was classified as moderate to very high, with the lowest P content at R4 at $22.22 \mathrm{ppm}$ and the highest at R5 at $43.31 \mathrm{ppm}$. The K-dd and Na-dd contents are classified as very low, with the lowest content at location R4 and the highest content at location R3. The Mg-dd content was classified as very low to moderate, with the lowest content at location R4 $0.20 \mathrm{me} / 100 \mathrm{gr}$ and the highest content at location R3 at $1.64 \mathrm{me} / 100 \mathrm{~g}$. The Ca-dd content was classified as very low to moderate, with the lowest content at location R4 $0.77 \mathrm{me} / 100 \mathrm{gr}$ and the highest content at location R3 at 8.49 me / $100 \mathrm{gr}$. KB values are classified as very low to low, with the lowest value at R4 4.64\% at the highest at R3 location at $25.13 \%$. CEC value is classified as moderate to very high, with the lowest CEC value at location R5 20.23 me / 100gr highest at $\mathrm{R} 3$ location at $42.39 \mathrm{me} / 100 \mathrm{gr}$. The $\mathrm{pH}$ value $(\mathrm{H} 2 \mathrm{O})$ in several research locations was classified as very acid, with the lowest $\mathrm{pH}$ at R2 5.12 and the highest value at R5 at 5.28.

Laboratory analysis results of soil chemical properties from soil samples taken in the former coal mining area of PT. SEM can be used to determine soil fertility status in the area. The results of the evaluation of the fertility status of researchers show that the former coal mining area of PT. SEM is classified as very low. It is expected that in the future reclamation areas at PT. SEM is paid more attention and its implementation is more improved, especially lime application and fertilizing plants because soil $\mathrm{pH}$ is still in the acidic category $(\mathrm{pH}<5.55)$ and the $\mathrm{P}$ element is classified as moderate to very high $(22.22-43.31)$ and $\mathrm{K}$ is very low (0.01 - 0.23), KB is still classified as very low to low (4.64-25-13), CEC is classified as low to very high $(20.23$ - 42.97).

At PT. SEM, PAF rocks are well managed by topsoil and subsoil overlay on the upper layers. The very small number of topsoils in forests in Kalimantan, especially in secondary forests, causes the PAF rock cover overlay generally from more than subsoil which has a lower $\mathrm{pH}$ than the topsoil. This results in lower soil $\mathrm{pH}$ in the reclamation area. The high phosphorus content available is due to the $\mathrm{pH}$ at the study location which is quite acidic. According to Adisoemarto (1994), the P element can be bound to the elements $\mathrm{Al}$ and Fe in acid soils.

Changes in soil physical and chemical properties in the former coal mining area of PT. senamas Energindo Mineral is caused when topping activities, especially nutrient soils, are 
not properly managed so that fertile soils are mixed with overburden or fertile soils overwritten by infertile soils. Because the soil is not well managed over time with the condition of the land not well organized, the nutrients such as C-organic (Mangkoedihardjo and April, 2012), N, P, K, Mg, Ca, Mn, KB during the rainy season dissolve or washed down resulting in reduced or loss of elements nutrient in the former coal mining area. According to Margaretha, (2010). Mining activities cause physical and chemical changes in the soil, thereby reducing the quality of the soil. In general, coal excavated soil is stacked on productive soil, with an inverted arrangement from the initial arrangement, top soil. In the first few years the area of the former coal mining is difficult to grow vegetation. This is caused by several factors, namely the soil is too dense, the structure of the soil is not extant, poor aeration and drainage and the soil is slow to absorb water. There are also chemical constraints such as extremely acidic $\mathrm{pH}$ and low soil fertility. This phenomenon is in line with Hardjowigeno (2003) changes in soil physical chemistry that occur such as changes in texture, structure consistency, boundaries between soil layers, while changes in soil chemical properties such as changes in nutrient content in the soil, C-organic, soil $\mathrm{pH}$, conditions like this causing ex-mining lands to be difficult to grow a variety of plants including for agricultural activities due to stunted plant growth and decreased soil productivity (Pribadi, 2012).

\subsubsection{Evaluation of Suitability of Cultivation Land of Eucalyptus and Sengon Plants on Former Coal Mining Areas}

Based on the analysis results of land suitability evaluation shows that the actual land suitability for eucalyptus plants and sengon plants is classified as marginal (S3). The limiting factor for sengon plants is the availability of nutrients (na) in the form of very low $\mathrm{K} 2 \mathrm{O}$. Therefore, if sengon plants are used as revegetation plants, the actual land suitability can be increased to potential suitability with the appropriate category (S1). Management that can be done is included in the moderate category with efforts to administer Potassium fertilizer in the form of $\mathrm{KCl}$.

The limiting factor for eucalyptus plants is nutrient retention (nr) in the form of C-organic which is classified as very low. Therefore, if eucalyptus plants are used as revegetation plants, the actual land suitability can be increased to potential suitability with the appropriate category (S1). Management that can be done is in the moderate category with efforts to add organic material / organic fertilizer.

The parameters to measure soil fertility are $\mathrm{CEC}$ value and soil $\mathrm{pH}$. $\mathrm{CEC}$ value is highly dependent on clay content, kinds of minerals and organic matter (Adisoemarto, 1994). To increase plant growth, soil acidity conditions that are near neutral are needed, while the $\mathrm{pH}$ of the soil at the former coal mining location is quite acidic. For this reason, liming is absolutely necessary to increase soil $\mathrm{pH}$. Improved soil quality can be seen after a longer period of time. Especially for sengon plants, it takes a long time ( $>11$ years) to improve the quality of the soil that approaches the land before it is mined.

Plants can grow well in the $\mathrm{pH}$ range of 4.0 to 8.5 although optimum growth will be achieved in the range of $\mathrm{pH} 4.5$ to 8.0, (Djaenuddin et al., 1994; Mangkoedihardjo and Samudro, 2014). As such, the mined land studied has a level of soil acidity suitable for forestry plants, forage and grazing. Giving lime is absolutely necessary to reduce the degree of acidity so that the land can be used to plant these types of plants.

Eucalyptus is able to grow both on marginal lands and in areas of swamps and water puddles, able to adapt to soils with poor drainage, fire resistance and tolerance to soils with low to high salinity. Eucalyptus in a variety of site conditions, both in the highlands and lowlands bordering coastal forests and growing monoculture. In addition, eucalyptus is resistant to heat and fire. Eucalyptus can live and grow again in 1 year with the condition of 
the leaves that can be picked. Eucalyptus roots consist of taproot, lateral roots, and secondary roots. The roots are straight and grow downward, lateral roots grow in the neck of the roots at the beginning of growth. Secondary roots spread at a depth of about $20 \mathrm{~cm}$ below the surface of the soil (Sunarto, 2003 in Kusumajati, E., 2017).

Based on the results of the land suitability evaluation analysis, that the Sengon plant has an actual land suitability according to marginal (S3) and can be increased to potential suitability into an appropriate category (S1). The limiting factors for sengon plants are nutrients (nr) which include base saturation (KB), very low $\mathrm{pH}$ and C-org. Besides nutrients, there are also available nutrient limiting factors (na) which consist of $\mathrm{P}$ and $\mathrm{K}$ nutrients which are classified as very low. Therefore, if sengon plants are used as revegetation plants, moderate management is needed with efforts to calcify using dolomite and fertilizing, especially fertilizer phosphorus in the form of SP-36 and TSP, as well as potassium in the form of $\mathrm{KCl}$. Sengon is a great business opportunity with easy maintenance and is a tempting thing for wood business people, until now the sengon plant is in the middle of a conversation among the people of Indonesia.

\section{CONCLUSION}

Based on the results of the study concluded as follows:

- Representative location for soil sampling and observation of the physical properties studied at the next research stage is determined at PT. Senamas Energindo Mineral which is administratively located in the Districts of East Hamlet, Karusen janang, and Awang District of East Barito Regency, Central Kalimantan Province.

- Based on the analysis results of land suitability evaluation, eucalyptus plants and sengon plants have an actual land suitability classified as marginal (S3). The limiting factor for sengon plants is in the form of very low $\mathrm{K} 2 \mathrm{O}$, while the limiting factor for eucalyptus plants is in the form of C-organic which is classified as very low.

\section{REFERENCES}

[1] Adisoemarto, Soenarto. 1994. Fundamentals of Soil Science. Erlangga, 2008, Jakarta.

[2] BPS, (2018) Central Statistics Agency (East Barito in Figures), Tamiang Layang.

[3] Djaenuddin., 1914. Land suitability for agricultural crops and forestry plants. Bogor Agricultural Research Institute 7 (1) Technical Report: 12-18.

[4] Hardjowigeno, S, 2003. Soil Classification and Pedogenesis. Jakarta; Akademika Pressindo.

[5] Kusumajati, E., 2017. Teaching Material for Introduction of Eucalyptus Plants, In Training on Capacity Building for Communities in the Utilization of Eucalyptus NTFPs.

[6] Mangkoedihardjo, S. and April, SAL. (2012). Compost On Evapotranspiration Bed Planted With Yellow Flag For Treatment Of Wastewater Containing Anionic Surfactant. Journal of Applied Sciences Research, 8(3): 1630-1633.

[7] Mangkoedihardjo, S. and Samudro, G. 2014. Research strategy on kenaf for phytoremediation of organic matter and metals polluted soil. Advances in Environmental Biology, 8(17): 64-67. 
Ermal Subhan, Salampak, Andria Elia Embang, Masliani, Yetrie Ludang, Adi Jaya

[8] Margareta, 2010. Utilization of Former Coal Mine Land with Mycorrhizal Biofertilizer as Sweet Corn Growing Media. Vol 1: 3; 1-10, 2010. ISSN hln. 2086 - 4825.

[9] Pribadi A, 2012. Reclamation of Former Tambanag Coal Land. Faculty of Agriculture. Yogyakarta; Veterans National Development University.

[10] Rahmawaty, 2002. Restoration of Former Mining Land Based on Ecological Rules, Faculty of Agriculture, University of North Sumatra, Medan.

[11] V. M. Ivonin, I.V. Voskoboynikova and E.Yu. Matvienko, Theoretical Concept of Adaptive Forest Land Reclamation of Agricultural Landscapes, International Journal of Civil Engineering and Technology, 9(13), 2018, pp. 95-103 